DOI: 10.1515/ausp-2015-0056

\title{
The Travelling Metaphor in Contemporary Terminology
}

\author{
Doina BUTIURCA \\ Department of Applied Linguistics, \\ Faculty of Technical and Human Sciences, Târgu-Mureş \\ Sapientia Hungarian University of Transylvania \\ butiurcadoina@yahoo.com
}

\begin{abstract}
External motivation, the classification and characteristics of this type of motivation - attributed to an impressive number of specialized terms in contemporary scientific languages - is the topic we propose to approach in our study. The motivated relationship between the signified object and the term and the metasemic motivation (in the case of change of meaning) are two of our general research directions. The definition of the metasemically motivated "travelling" metaphor in terminology, the cultural sources of this type of metaphor, the patterns of interdisciplinarity it creates in the corpus of terms and/or specialized discourse, and the multi- and plurilingual dimension represent the specific objectives of our research (applicative and theoretical). The descriptive-linguistic method, the contrastive method are the methods applied in the study to show the extent to which the condition of precision of the specialized meaning is met in the different languages. The results of this research reveal that external motivation, the metaphor, represents one of the creative forces of present terminology.
\end{abstract}

Keywords: motivation, metasemic, metaphor, multilingual, terminology

\section{Theoretical framework}

"Motivation" is a characteristic of specialized terms as opposed to the majority of linguistic signs of arbitrary (or unmotivated) character in terms of the extrinsic relationship between the concept and extralinguistic reality. Motivation can be analysed from several perspectives.

There is an absolute motivation: the sound form "evokes traits of the designated content” (Dicționar de Ştiințe ale Limbii 2005: 330). The interjections sst! deh! as well as the onomatopoeia hodoronc-tronc! tronca-tronca! reproduce sounds, noises in a spontaneous manner. There are words with a phonetic symbolism that also reproduce spontaneous noises: cotcodăceală ('cackle'), a mârâi ('to growl'), 
a hârâi ('to growl'), etc. Relative motivation is achieved not only on the level of phonetic elements.

Scholarly literature describes other types of motivation as well: a. internal motivation is of a diachronic nature. The disappearance of basic words led to the disappearance of internal motivation; b. motivation by semantic elements (such as pro-, retro-, super-, etc.) is a constant of the common lexicon but also that of the specialized lexicon as well. The same internal motivation determines compound words (tărâie-brâu 'punk') and the compounds used in science (morfologie 'morphology,' pediatrie 'paediatrics').

Synchronic motivation is another type of internal motivation and is manifested both on the level of the lexicon and/or on the morphological level. We talk about paronymic motivation/homonymic motivation: the primary signs capră ('1. goat, 2. leapfrog'), broască ('1. frog, 2. lock') are reference terms to express distinctive features from the signified field of the new signs formed based on common features that exist between the objects designated by the primary sign and the secondary sign (formal identity in both examples). This characteristic defines the homonyms capră ('1. goat, 2. leapfrog'), broască ('1. frog, 2. lock'), and lac ('1. lake 2. lacquer'). The primary term is always arbitrary. For instance, the word lac ('lake'), designating the surface of a body of water is arbitrary in its internal relationship as in its report to external reality, to the referential plane. The derived term, however, designating the substance that gives shine to nails/ the parquet, etc. is internally motivated based on resemblance on the ontological plane (reflected on the plane of consciousness), the geographical reality and lac ('lacquer'), the gloss used in cosmetics/the chemical industry.

External motivation is based on developing a relationship between the signified object and the signifying form, outside the linguistic system. Metasemic motivation is a type of external motivation, manifested in the case of semantic changes in contemporary terminology/specialized languages. The primary meaning of a word in the common languages and/or a specialized language can acquire numerous secondary meanings, derived, thanks to the "meta" function (the semantic and informational, communicative ensemble) that contributes to the creation of several term corpora through semantic changes. Metasemic motivation is a characteristic of the language of science, of the connected domains of activity, and it is a source of creation of the terminological metaphor.

\section{Metasemic motivation in the specialized languages}

Vasile Bahnaru creates a classification of metasemy, proposing the term "implicative metasemy," which manifests itself in two ways (Bahnaru 1988: 156); these are: 1 . "aesthetic implicative metasemy" and 2. "denominative implicative metasemy". 
1. If the first typology is manifested by a poetic image which overlaps the idea of the message of artistic creation, 2. denominative implicative metasemy has the function to designate the relationship between a sign and the extralinguistic reality or the referent in its acception of a particular object belonging to a given class (the colleague in front of you), belonging to the reference to action (to read, not to sing), the quality of the name (beautiful, gentle), to the attribute of the action (brotherly, English). The general patterns of achieving implicative metasemy differs from the vocabulary of natural languages to that of specialized languages. On the lexical level, metasemy is achieved through general patterns the actual manifestation of which is specific to each language. These are patterns that contribute, on the one hand, to the emergence of new meanings, contained in the concept of a word (University: Technical University, University of Medicine, People's University of Arts). Secondly, the concrete patterns of implicative metasemy are relevant through semantic mutations that generate homonymy (lexical/morphological): lac ('lacquer, nail polish') - cosmetic product; lac ('lacquer') - chemical product for maintenance; lac ('lake') - stretch of water, etc.

Eugen Coşeriu considered metasemy a type of cognitive (unitary expression) and/or an aesthetic metaphor (spontaneous and immediate of a vision, of a poetic intuition), a momentary identification of different objects (Eugeniu Coşeriu 1952, 2009) realized on the level of the signified.

The type of motivation of the terminological metaphor is metasemic in its nature, based on modifications of meaning, of conceptual traits realized based on analogy, etc. It is a type of motivation that is realized on the level of the bilexical and pluri-lexical metaphor. Within the medical metaphor "amaurotic cat's eyes" [designates in ophthalmology a type of unilateral blindness, accompanied by a shiny aspect of the pupil (Dicționar medical 2007: 754)], there is a primary signifier, the "eye" (in the phonetic expression "cat's eyes," it is also another metaphor), which designates the anatomical element. This first signifier forms a secondary signifier (illness of the eye) through the semantic relationship it establishes with the determinatives "cat's" and "amaurotic," in context. A relatively similar situation of metasemic motivation exists in the medical metaphor "caput medusae," which designates a visible collateral circulation in the abdominal wall, created by the dilating of the paraumbilical veins as a result of the permeabilization of the umbilical vein due to portal hypertension (Dictionar medical 2007: 308). The primary signifier (the phonetic form "head") designates through analogy the mushroom-shaped form of blood vessels. By the relation of meaning established with the meaning of the determinative "medusae," this first signifier becomes a secondary signifier (based on the conceptualization of the "visible," "transparent" character of the disease).

We can observe from the given examples the complexity of the concept in establishing differences in meaning, in differentiating the terminologies ("eyes"/ 
“cat's eyes” / “amaurotic cat's eyes,” etc.) The surface level of the polilexical metaphors is heterogeneous, including in terms of linguistic expression different syntagmatic units: med. active serum (Lat. serum, zer), med. brush fillets, med. amaurotic cat's eyes, med. caput medusae, etc.

The complexity of the context is not given by the surface level but by the deep levels, the different degrees of fixing the elements of the metaphor.

The degree of the logical and semantic cohesion of bi- and polilexical metaphors, their age, and common semic basis impose stable structures and stable contexts.

\section{The terminological metaphor: definition, classification}

Linguistics differentiates between scientific metaphorization and terminological metaphorization. 1. The notion of scientific metaphorization has a broad scope, including both conceptual metaphorization and theoretical metaphorization. The complexity is given by the correlation with the creative, psychological, and theoretical dimension of the process itself. The terminological metaphor has a general reference upon three interdependent levels: the gnoseological level (that of the theory of cognition), the conceptual level, and the semiologic level (code and information character).

By terminological metaphor, we understand a functional variant of the scientific metaphor. The analysis of the types of terminological metaphors we consider is carried out on two levels (Oliveira 2009):

1. at the denominative level (of linguistic realization)

The word canal was used in everyday Latin with the meaning 'ditch, gutter' and belongs to the preconceptual pattern of the "habitat". It has come to be used by current terminology, by several specialized languages being used interdisciplinarily.

In the medical language, for example, canal (Fr./ En. duct, canal, channel NA: ductus, canalis) is one of the denominative metaphors that names the general concept of "space of leakage or passageway for organic matter (food, blood), air or other anatomical structures (vessels, nerves).” The tubular structure that dominates the products of the secretion of an exocrine glands. It is a metaphor synonymous with other two denotative constructs, "conduct" and "duct".

2. on the level of abstract images (of concepts)

As there has been a term in the example, a denotative metaphor, 56 conceptual metaphors have been created through conceptual and semantic expansion in the English, French, and pan-Romance terminologies in general: alveolar canal, deferent canal, ion channel, tarsian channel, etc. Similarly, in the case of the denominative metaphor thorax, the following metaphorical concepts have been created through expansion: med. Ro. torace în butoi (cf. Fr. thotax en tonneau; 
Eng. barrel chest); Ro. torace în carenă (cf. Fr. thorax en carène; Eng. chicken breast); med. Ro. torace în clepsidră (cf. Fr. thorax en sablier; Eng. rachitic chest); med. Ro. torace în pâlnie (cf. Fr. thorax en entonnoir; Eng. tunnel chest), etc.

\section{The "travelling" metaphor in terminology}

The following are part of the so-called "travelling" metaphors: Ro. blestemul Ondinei 'Ondine's curse,' Ro. călcâiul lui Achile 'Achilles's heel,' mărul lui Adam 'Adam's apple,' sindromul Alice în Țara Minunilor 'Alice in Wonderland syndrome,' etc. They are used in sociolinguistics, especially in the specialized discourse with a high degree of science popularization. In a general sense, the "travelling" metaphor is used in the study of the vocabulary and focuses on quasi-universal constructions belonging to the European heritage (Chiş 2005). A few examples: from Annas to Caiaphas, from Alpha to Omega, Achilles's heel, Pandora's box, Penelope's canvas, the bed of Procustes, etc. In specialized languages, the travelling metaphors, besides the aforementioned culture-specific words, include several source domains. Culture-specific words and idiomatic expressions may have an expressive function in interpersonal communication and/or in the language of the media, in the language of fiction, etc. The terminological metaphors of "hard" science go beyond these functions carrying the expressive vs. subjective dimension through the cognitive and logical status of metaphorical constructions: 1. they contribute to the creation of new scientific concepts; 2. they "name" concepts through analogy. We believe that through the conceptual systems and subsystems of contemporary science they belong both to Europe and the whole world, the architecture of the Greek and Roman houses, the way to represent the real world and the world beyond ancient civilizations, the way to understand phenomena, elements of material civilization, etc.; Greek-Latin mythological names (Atlas, Axis, names of vertebrae in Anatomy), Norse mythology, oriental tales, literary works, etc.

The source domains of the travelling metaphor are varied, their importance consisting in the ensuring of the transparency necessary for specialized communication.

The Greek and the Roman house is one of the most productive domains for the terminological and/or conceptual metaphor in medical terminology, in the NA language, and in economy. Economy is one of the many conceptual metaphors coined from ӧ̈ко - and $v о \mu($ o)-, vó $\mu о$, which entered European languages through Latin. In the common lexicon of the Greek language, оїкоร, оїкía had multiple meanings: 'house, home, environment'; 'hall, auditorium'; 'residence'; 'goods, property, fortune, country,' and $v o \mu(o)$ - meant 'custom, way of being; order; law, right'. The acception of a way of organizing private property conferred by Xenofon to the term is Xenophon; it is nuanced by Aristotle for whom oikonomia meant 
'the art of homemaking' and 'the art of trade'. The term oeconomia (Fr. économie; Sp. economia; It. economia; Rom. economie; En. economy) can be found in Latin used by Quintilian almost two millennia ago, used with an empirical acception.

The pattern/the anthropological resource domain is particularly productive in the medical conceptual constructs: med. silhuette sign; med. blue toe syndrome; med. long fibres syndrome; med. red man syndrome; med. silvery hair syndrome; med. crutch palsy, etc. By the "known/determined" characteristic conferred by the definite article (syndrome/sign/disease), the conceptual sphere of the denoted is expanded (to be compared with: med. sindromul picioarelor fără repaus 'Restless Legs Syndrome' with sindrom al picioarelor fără repaus - 'Syndrome of Restless Legs,' the latter created for comparison), the apparently subjective charge being neutralized. The logical-semantical convergence of both terms is used in the cognitive approach: med-restless legs + syndrome; med. crocodile tears + syndrome, etc. On the level of expression, conceptual constructs are polylexical terminological syntagms, in which the determinant identifies notional characteristics (matter, object, possessor, class, whole, part, etc.) of denotation. The pattern manus has known in its own evolution moments of expansion, in which several conceptual constructs have been realized based on analogy. Manu militari with a referent in criminal law is a conceptual metaphor used with the meaning 'by public force'. We can find the manus model on the macrosystemic level, in the corpora of terminological constructs with referents in the management of marketing: Ro. manufactura (Fr. manufacture; Sp. manufactura; En. manufactory); Ro. manuscris (Fr. manuscrit; Sp. manuscrito; En. manuscript), in the language of social sciences (Ro. manipulare; Fr. manipulation; Sp. manipulacion, etc. as opposed to the English language, where the equivalent handling is used), in market economy (Ro. manufacturier; Fr. manufacturier; Sp. manufacturero, etc). The term management has the same root, manus, but it has acquired a specific meaning: discipline of economics having as its aim the study of the application of control and leadership politics, strategies, and decisions in economic and social activities, depending on the domain, in order to obtain the desired results regarding the stability and development of these activities. Management (< En. management; Fr. management; Sp. management) is a universal conceptual construct to which an adequate equivalent is hard to be found in the languages of contemporary Europe. Terms such as Ro. administrație $(<$ Fr. administration), Ro. organizare ( $<$ Fr. organiser), Ro. gestiune $(<$ Fr. gestion, Lat. gestionem), Ro. conducere ( $<$ Lat. conducere) do not include all the meanings within the concept of management. The recent term of leadership borrowed from English, which is used more and more insistently in the Romanian language, designates only one conceptual feature of the notion of management.

The socio-economic/political/geographic pattern, etc.: med. Persian Gulf Syndrome; ec. Black Friday; ec. Black Tuesday, etc. is expanding in contemporary 
specialized languages. Based on this pattern, extremely complex metaphors are created with different syntagmatic realizations. The determiners, usually proper nouns, create the extension through conceptual traits related to space, to time/ period, to possessor, to identity, etc. These are metaphors built upon names of geographical regions and countries (med. Persian Gulf Syndrome), etc., and possess a high degree of implication in the terminology of different domains.

The syntagms in this category illustrate Roman Jakobson's hypothesis that in describing metaphors one should not exaggerate the challenge of semantic approach (v. Mihaela Mancaş in Dicționar de Ştiințe ale Limbii 2005: 308). In the syntagm Persian Gulf Syndrome, the semantic connection is not a powerful one, so we cannot mention the identity of the semes regarding the metaphorical term and the metaphorized but one of identifying a conceptual trait of the denoted ("varied symptoms of the Persian Gulf War veterans, 1990-1991"). The conceptual constructs having as their resource domain socio-economy, geography do not modify/substitute a trait, but create a new notion through adding "identifiers". We should not confuse the class of metaphors of designation with syntagms containing a proper name, also, designative, non-transparent: Thales' theorem, Euclid's postulates (formulae, in a traditional sense), Avogadro's number (numbers) and/or in nominative: Apert disease, Coandă effect, Lance sign, Cotzen syndrome, Conn probes, Casoni reaction. The zoomorphic preconceptual pattern is not particularly productive: med. semnul ventuzei 'the sign of the suction valve'; med. sindromul lacrimilor de crocodil 'crocodile tears syndrome'; med. sindromul leopard 'the leopard syndrome,' etc. The terminological metaphor capital (cf. neutre pl. Latin capita - capete) designates the concept of the totality of financial resources of an enterprise (money, stocks), creating a conceptual basis for about 23 metaphors of abstract (conceptual) images in the international business language: Ro. capital activ negativ (Fr. capital actif négatif, Sp. capital activo negativo,); Ro. capital circulant (Fr. capital actif circulant; It. capitale di circolazione; Sp. capital circulante ); Ro. capital uman (Fr. capital humain, Sp. capital humano, It. capitali umani), etc. The notion is connected to the custom of Romans who owned animals to lend a certain number of "capita”.

The terminological metaphor created on the basis of habitat and that of material culture belongs equally to the European material heritage: ec. economie 'economy'; med. semnul scăriței 'ladder sign'; med. semnul sertarului 'drawer sign'; med. sindromul de ansă oarbă 'blind loop syndrome'; med. sindrom vestibular ('vestibular syndrom'); med. suberoză 'suberosis,' etc. The GrecoLatin mythology is the resource domain that covers both from the conceptual and linguistic point of view an impressive number of scientific terms formed by analogy. In the English and Romance terminologies, there are about 17 metaphorical constructs formed on the basis of the preconceptual model moneta - semantically related to the verb moneo, ere, ui, itum (to recommend, to warn), 
but also the epithet "advisory," which was assigned to Juno, the goddess (the Roman mint was placed in the Temple of Juno Moneta). The doublet moneda and moneta circulates in international terminology, the first one having a Greek etymon, the second a Latin etymon; both forms competed in forming the conceptual metaphor of moneda 'money, instrument of payment': Ro. monedă comercială (Fr. monnaie commerciale; Sp. moneda comercial); Ro. moneda fără valoare; Ro. moneda din aur şi argint (Fr. monnaie en or et argent; Sp. moneda de oro y plata, etc...).

Other resource domains of the travelling, terminological, and conceptual metaphors are: the pattern of the organic: med. stearină 'stearin,' etc; the mineral/ vegetal kingdom: med. sindromul prafului organic toxic 'toxic organic dust syndrome'; med. spicul 'spicule'; med. spor 'spore'; med. stafilom 'stafiloma'; med. talie 'tiller' (în Lat. talea - tiller), etc.

Erudite metaphors: med. semnul arlechinului 'Harlequin sign'; med. semnul crenelului 'embattled sign,' med. blestemul Ondinei 'Ondine's curse,' etc.; the interdisciplinary terminological metaphor: sindromul de calotă 'calotte syndrome'; med. sindromul de linie mediană 'median ligament syndrome,' etc.; religious metaphor: med. semnul rugăciunii mahomedane 'the sign of the Mohammedan prayer,' etc; the metaphor with the substrate of forms of civilization: med. semnul steagului 'flag sign'; med. sindromul de restaurant chinezesc 'Chinese restaurant syndrome'; med. specul 'speculus,' etc.

The study of the terminological metaphor in general, that of the travelling metaphor is extremely complex. The utility of metaphorical constructs (of concept/image and denomination) is given by three aspects: the degree of fluidity of information in specialized communication, transparency of meaning and notional characteristics, and preservation of the specificity of national languages.

\section{Sources}

Bidu-Vrănceanu, Angela et al. 2005. Dicționar de Ştiințe ale Limbii. Bucharest: Editura Nemira.

Mancaş, Mihaela. 2005. Dicționar de Ştiințe ale Limbii. Bucharest: Editura Nemira.

Rusu, Valeriu. 2007. Dicționar medical. Bucharest: Editura Medicală. 


\section{References}

Bahnaru, Vasile I. 1988. Mutații de sens: cause, modalități, efecte. Chişinău: Editura Ştiința.

Chiş, Dorina. 2005. O importantă sursă terminologică-numele proprii. Timişoara: UTT.

Coşeriu, Eugeniu. 2009. Omul şi limbajul său. Iaşi: Editura Universității Al. I. Cuza.

Oliveira I. 2009. Nature et fonction de la métaphore en science. Paris: Harmattan. 